UDC $78.03+782.1 / 784.95$

DOI https://doi.org/10.31723/2524-0447-2020-30-1-16

\author{
Na Wang \\ ORCID: 0000-0001-6014-1604 \\ Applicant at the Department of Music History and Musical Ethnography \\ Odessa National A. V. Nezhdanova Academy of Music \\ WangnaOd19@gmail.com
}

\title{
OPERAS ON GOGOL'S PLOTS IN THE COMPOSITIONS OF CONTEMPORARY COMPOSERS: FROM LIBRETTO TO THE PROBLEM OF PLOTOLOGY
}

Research objective is to identify the genesis of opera creativity based on Gogol's plots in the context of defining and substantiating the historical conditions and theoretical parameters of the phenomenon of plotology. This necessitated the development of a typological aesthetic approach to opera plotology, typological criteria for the study of thematic opera content. The methodology of the work is determined by the interaction of theoretical and historical approaches to opera plotology; musicological analytical, aesthetic-psychological, historical, semiological and textological approaches are noted as presenters. The scientific novelty of the article lies in the fact that it offers a comprehensive description of operas based on Gogol's plots as an actual trend in musical art. Along with this, the article examines the problem of an artistic plot in the light of opera issues and in projection onto the structural and compositional logic of the opera text. Conclusions. The embodiment of N. Gogol's works in the opera genre is becoming an established trend in the development of this genre sphere in the context of the evolution of world opera. The creative heritage of $N$. Gogol has attracted and still attracts the attention of representatives of various national composing schools and different generations. Today, the history of the development of musical gogoliana has more than a century and a half, and we can confidently speak of its significant influence on artistic and cultural trends and the musical and historical process in general. On the basis of the analysis of literary studies devoted to the issues of plot and plotology, the interdependence and dependence of the artistic plot on the compositional principles of constructing the composition becomes indisputable. It should be noted that this interdependence can take different forms in different types of art, at the same time it also has common dominant artistic and ontological features, which are most pronounced in literary and musical works. These forms and their dominant features should be understood as a system of functioning of iconic complexes and the principle of organizing individual parts as part of a whole composition, including a comparison of plot episodes, and the order of reporting the course of events, and the distribution of these events in time.

Key words: Gogol's plot, opera libretto, plotology, opera drama, musical Gogoliana, interpretation of literary source.

Ван На, здобувач кафедри історії музики та музичної етнографії Одеської національної музичної академії імені А. В. Нежданової

Опери на гоголівські сюжети у творчості сучасних композиторів: від лібрето до проблеми сюжетологіï

Мета роботи полягає у виявленні генезису оперної творчості на гоголівські сюжети в контексті визначення й обгрунтування історичних умов і теоретичних параметрів явища сюжетології. Це зумовило необхідність розвитку типологічного естетичного підходу до оперної сюжетології, типологічні критерії вивчення тематичного оперного змісту. Методологія дослідження визначається взаємодією теоретичного й історичного підходів до оперної сюжетології; як провідні відзначаються музикознавчий аналітичний, естетико-психологічний, історичний, семіологічний та текстологічний підходи. Наукова новизна статті полягає в тому, що в ній пропонується комплексна характеристика опер на гоголівські сюжети як актуального напряму в музичному мистецтві. Водночас у статті розглядається проблема художнього сюжету у світлі оперознавчих питань і у проєкції на структурно-композиційну логіку оперного тексту. Висновки. Втілення творів М. Гоголя в оперному жканрі стає усталеною тенденцією в розвитку даної жанрової сфери в контексті еволющії світового оперного мистецтва. Творча спадщина М. Гоголя привертала і привертає увагу представників різних національних композиторських шкіл та різних поколінь. Натепер історія розвитку музичної гоголіани налічує вже понад півтора століття, $i$ з упевненістю можна говорити про ї̈ значний вплив на художньо-культурні тенденції та музичноісторичний процес загалом.

У результаті проведеного аналізу літературознавчих досліджень, присвячених питанням сюжету i сюжетології, стає явною взаємозумовленість $і$ залежність художнього сюжету від композиційних принципів побудови твору. Відзначимо, що дана взаємозумовленість може набувати різних форм у різних видах мистецтва, водночас має і загальні основні художньо-онтологічні ознаки, які найбільше 
проявляються в літературному і музичному творах. Зазначені форми і їхні головні ознаки варто розуміти як систему функціонування знакових комплексів і принцип організації окремих частин у складі цілого твору, що включає $і$ зіставлення сюжетних епізодів, і порядок повідомлення про перебіг подій, $i$ розподіл даних подій у часі.

Ключові слова: гоголівський сюжет, оперне лібрето, сюжетологія, оперна драматургія, музична гоголіана, інтерпретація літературного першоджерела.

Ван На, соискатель кафедры истории музыки и музыкальной этнографии Одесской национальной музыкальной академии имени А. В. Неждановой

Оперы на гоголевские сюжеты в творчестве современных композиторов: от либретто к проблеме сюжетологии

Цель статьи заключается в выявлении генезиса оперного творчества на гоголевские сюжеты в контексте определения и обоснования исторических условий и теоретических параметров явления сюжетологии. Это обусловило необходимость развития типологического эстетического подхода к оперной сюжетологии, типологические критерии изучения тематического оперного содержания. Методология исследования определяется взаимодействием теоретического и исторического подходов к оперной сюжетологии; как ведущие отмечаются музыковедческий аналитический, эстетико-психологический, исторический, семиологический и текстологический подходы. Научная новизна статьи заключается в том, что в ней предлагается комплексная характеристика опер на гоголевские сюжеты как актуального направления в музыкальном искусстве. Наряду с этим в статье рассматривается проблема художественного сюжета в свете опероведческих вопросов и в проекции на структурно-композиционную логику оперного текста. Выводы. Воплощение произведений Н. Гоголя в оперном жсанре становится устоявшейся тенденцией в развитии данной жканровой сферы в контексте эволюции мирового оперного искусства. Творческое наследие Н. Гоголя привлекало и привлекает внимание представителей различных национальных композиторских школ и разных поколений. На сегодняшний день история развития музыкальной гоголианы насчитывает уже более полутора столетий, и с уверенностью можно говорить о ее значительном влиянии на художественно-культурные тенденции и музыкально-исторический проиесс в иелом.

В результате проведенного анализа литературоведческих исследований, посвященных вопросам сюжета и сюжетологии, становится бесспорной взаимообусловленность и зависимость художественного сюжета от композиционных принципов построения произведения. Отметим, что данная взаимообусловленность может принимать различные формы в разных видах искусства, вместе с тем имеет и общие доминирующие художественно-онтологические признаки, которые сильнее всего проявляются в литературном и музыкальном произведениях. Указанные формы и их доминирующие признаки следует понимать как систему функционирования знаковых комплексов и принцип организации отдельных частей в составе целого произведения, включающего и сопоставление сюжетных эпизодов, и порядок сообщения о ходе событий, и распределение данных событий во времени.

Ключевые слова: гоголевский сюжет, оперное либретто, сюжетология, оперная драматургия, музыкальная гоголиана, интерпретация литературного первоисточника.

Relevance of the article. Musicological consideration of an opera composition almost always begins with an acquaintance with the literary fundamental principle of the composition, its plot outline as a source of the dramaturgy structure of the entire composition. Although it should be noted some one-sidedness of the study of the libretto, which often consisted of a discussion of the minimum information about the author of a literary composition and about the composition itself, as well as a comparison of the literary source with its subsequent interpretation by the librettist. Therefore, the study of the libretto as the fundamental principle in the creation of an opera composition and the artistic foundation of an opera composition, which has its own structural and compositional principles and semantic properties, becomes one of the most important tasks in modern musicology.

Nikolai Gogol's literary heritage has attracted the attention of Russian and Ukrainian composers since the last third of the XIX century. As you know, in a fairly short period of time, a number of operas have appeared, the libretto of which is based on the compositions of N. Gogol, among which are the operas of P. Tchaikovsky, M. Mussorgsky, N. Rimsky-Korsakov, N. Lysenko. In the panorama of Gogol's plots for composers, the most attractive turned out to be folklore-fantastic, heroic and comedy, in which the national-everyday theme with its indescribable flavor occupied one of the leading places. At the same time, sharp accusatory satire or dramatic compositions attracted the attention of composers only in the XX century, the first of whom was D. Shostakovich, who finished the opera called "The Nose" in 1928.

The aim of the article is to identify the genesis of opera creativity based on Gogol's plots in the context of defining and substantiating the historical conditions and theoretical parameters of the phenomenon of plotology. This necessitated the development of a typological aesthetic approach 
to opera plotology, typological criteria for the study of thematic opera content. The methodology of the work is determined by the interaction of theoretical and historical approaches to opera plotology; musicological analytical, aesthetic-psychological, historical, semiological and textological approaches are noted as presenters.

The scientific novelty of the article lies in the fact that it offers a comprehensive description of operas based on Gogol's plots as an actual trend in musical art. Along with this, the article examines the problem of an artistic plot in the light of opera issues and in projection onto the structural and compositional logic of the opera text.

Presenting the main material. Among the most demanded Russian writers, whose works became the basis for many opera compositions, one should name N. Gogol, the significance of his work for the development of modern musical theater, in particular opera, is extremely important, since without his plots it is already impossible to imagine either Russian or Ukrainian nor contemporary music in general. This, of course, is explained by the genius of the writer, but also by the variety of themes, images of his compositions, their genre nature, the presence of vast zones of lyrics and grotesque, brightly and vividly prescribed everyday environment, national flavor, mainly Russian and Ukrainian, which are very valuable for opera plot quality.

The aesthetic and worldview views of N. Gogol were formed in the first third of the XIX century, the artistic atmosphere of which was characterized by the mutual influence and dialogical interaction of such stylistic trends as sentimentalism, classicism, romanticism and early realism, which explained some of the most significant trends in the writer's work. Among the most notable there are the combination of the expressed principles of romanticism and lyricism with realism and grotesque, which is revealed through the genre and stylistic diversity of his works, which determined the attractiveness of N. Gogol's compositions not only for readers and researchers, but also for composers.

Therefore, the interpretation and reinterpretation of N. Gogol's compositions in opera is an extremely interesting topic, and although there are already studies that raise the problem of studying the writer's creative heritage, the scale and multi-vector nature of the further life of Gogol's subjects in other spheres of art is so obvious that one can confidently assert that the beginning of the study of this phenomenon has just begun. The compositions of N. Gogol were actively addressed by composers of the XIX and XX centuries and they continue to address nowadays. New musical interpretations of Gogol's texts appear, performances and musicals are staged, films are released in the drama of which music plays an essential role.

Beginning with operas created in the last third of the XIX-XX centuries, including "Sorochinskaya Fair" and unfinished "Marriage" by M. Mussorgsky, "May Night" and "Christmas Eve" by N. Rimsky-Korsakov, "Cherevichki" by P. Tchaikovsky, "Christmas Night", "The Drowned Woman" and "Taras Bulba" by N. Lysenko, "The Marriage" of A. Grechaninov, "The Nose" and "The Players" by D. Shostakovich, the opera-ballet "Viy" by V. Gubarenko and others, the appearance of Gogol's plots on the opera stage in the new composer's reading is becoming a stable feature of the modern opera house. On the verge of the XX-XXI centuries, interest in the subjects of Nikolai Vasilyevich not only does not wane, but rather we can talk about the growing attention to the work of the great writer among contemporary composers.

It should be noted that N. Gogol's subjects are in demand far beyond the borders of the Russian empire and the entire post-Soviet space. At the turn of the XIX and XX centuries in Argentina, Norway and France, compositions on Gogol's plots appear, and three operas are created in different countries, embodying the heroic-epic images of Gogol in a romantic key, the basis of the libretto in all three cases of referring to the Gogol heritage is "Taras Bulba"("Taras Bulba" by Arthur Berutti, "Cossacks" by Catharinus Elling, "Taras Bulba" by Marcel Russo). In the second half of the XX century in the Czech Republic, Serbia, Germany, China, the operas "The Inspector General" by Werner Egk, "The Marriage" by Bohuslav Martinu, "Notes of a Madman" by Stanoilo Raichic, "The Return of Khlestakov" by Gizelkher Klebe, "Wolf's Village" ("Wolf Cub Village") by Guo Wenjing. It should be noted that if in the XIX and partly in the XX centuries among Gogol's plots, composers gave preference to fantastic, genre-everyday and comedic ones, then in the second half of the XX and up to the present day it is harshly satirical, grotesque or profoundly psychological plots, including one of the most complex and psychologically tense "Notes of a Madman".

It should be noted that in addition to operas based on the plots of N. Gogol's compositions, which, in our opinion, occupy a central place in the musical gogolian, composers of different eras have written numerous compositions in various genre directions - ballets, symphonic paintings, instrumental and orchestral suites, program overtures, chamber works, and many others. In this 
regard, the issues of studying the opera libretto and the plot of the literary source as the basis for constructing the concept of an opera libretto are becoming especially relevant and required.

The theoretical aspects of the study of the opera libretto appear as a separate direction in musicology only in the XX century, also in works devoted to the problems of opera drama by M. Druskin and B. Yarustovsky. These authors point to the extreme importance and significance of the literary primary source as the verbal basis of the opera, thanks to which it is possible to delineate the boundaries of the narrative, build plot lines, which largely determines the structure of the entire composition, since it "determines the verbal expression of the actions and experiences of the characters" [6, p. 148].

In the works of T. Nilova it is indicated that in many cases the verbal level or literary layer of an opera composition anticipates the creation and formation of a musical composition, it is a determining factor in the construction of the structural and compositional foundations of a work and determines its artistic content. Based on the musicological analysis of the libretto phenomenon, T. Nilova proposes a typology of stage situations that are characteristic of a number of operas (for example, "story", "prediction", "meeting", "parting", etc.) Thus, the author identifies one from the methods of analyzing opera text (see [3; 4]).

Numerous works are devoted to the musicological consideration of the libretto problem, among which the works of G. Ganzburg deserve special attention. The researcher believes that such a research direction as "librettology studies not music and literature, but their interaction. The focus of librettology is not the word and not the music, but the border between them, the zone of adherence, interconnection, and interpenetration.

With this approach, the researcher simultaneously deals with intonation, melody, harmony, polyphony (that is, everything that studies musicology), and phonetics, syntax, versification, stanza (that is, many of the aspects that philology studies)" [2, p. 244]. The author believes that the objects studied by librettology cannot be fully attributed either to musicological or literary studies, and "the composition of each composer is interested in librettology to the extent that the music of this composer is associated with the word" [2, p. 244]. Therefore, in the center of the study of librettology is the composition of those composers "in whose heritage synthetic genres constitute the core, and those in whose heritage these genres form the periphery" [2, p. 245].

At the same time, the musicological study of the libretto is directly related to the already formed basis of an opera composition, while often many parameters that lie in related areas of humanitarian knowledge turn out to be necessary in the study of opera and those mechanisms that influence the formation of an opera plot. In this case, the concept of plotology turns out to be much more accurate and methodologically important in a comprehensive examination of the opera plot. Its main theoretical basis is literary criticism, constantly develops approaches to such means of organizing a verbal literary text as theme, motive, plot, composition, disposition. Compared to music, these concepts have a different meaning, because they are conditioned by the material of the literature, the verbal form of presentation. But, on the other hand, it is precisely on the parallels with the philological position that it is possible to build musicological plotology, especially in such an industry as synthetic, opera art is always associated with the word. The use of such musicological approaches will ensure the identification of deep structural-compositional and artistic-semantic levels in such a complexly organized text as the works of N. Gogol.

In philological science, plotology in its methodological and analytical sense originates in the works of A. Veselovsky, M. Bakhtin, Y. Lotman, B. Tomashevsky and other researchers. Based on literary compositions, we can conclude that plotology is the comprehension and logical presentation of the plot as a way of telling, its structure and functions in the system of folklore and literary composition.

The plot of a literary composition and an opera libretto is a kind of conditional really, fixed with the help of a verbally designed text. Whatever genre or specific direction this textual device belongs to - in epic, drama or lyric poetry - it primarily serves to display events in the life of characters in a literary or opera composition, as well as their actions in space and time. It is this side of artistic creativity (the course of events, usually consisting of the actions of the heroes, reproducing the chronotopic dynamics of phenomena) is designated by the term plot, it is natural that this word also has the meaning of an object and theme, but in the logic of the plot formation of the text, these concepts take on separate functional positions.

Therefore, the plot should be considered as a kind of communicative mechanism for displaying certain facts of life and an artistically purposeful system of events. The specified artistic expediency determines a free interpretation and free treatment of the order of events in comparison with the real life, in other words, it has its own eventual logic, which should be especially paid attention to 
when working with texts as multilevel in terms of meaning as the works of N. Gogol. Therefore, it is necessary to separate and distinguish between the plot and the fable, since the plot appears as an actual, real reality that has already taken place, and the plot should be understood as the author's transformed reality, a sphere of new artistic imagery. As A. Veselovsky noted, the plot is an artistically constructed distribution of events [1]; B. Tomashevsky noted that in the plot we find the action of the composition in its entirety, as a real (just for art work) chain of depicted movements [5].

Based on what has been said, the main unit of the plot of a literary or opera composition becomes movement, the intensity, brightness and dynamics of which determine the stages in the development of the plot, which determine the general drama of the composition. In this case, the concept of movement occupies a central position, since, on the one hand, it fully corresponds to the immanent semantic dynamics of an art work and is an expression of the essence of music, on the other hand, it becomes a prerequisite for artistic creativity as it conveys the psychological dynamics and mobility of consciousness, which is also inherent in musical art, since in it the phenomenon of psychological movement is expressed extremely clearly.

Conclusions. The embodiment of N. Gogol's works in the opera genre is becoming an established trend in the development of this genre sphere in the context of the evolution of world opera. The creative heritage of N. Gogol has attracted and still attracts the attention of representatives of various national composing schools and different generations. Today, the history of the development of musical gogoliana has more than a century and a half, and we can confidently speak of its significant influence on artistic and cultural trends and the musical and historical process in general.

On the basis of the analysis of literary studies devoted to the issues of plot and plotology, the interdependence and dependence of the artistic plot on the compositional principles of constructing the composition becomes indisputable. It should be noted that this interdependence can take different forms in different types of art, at the same time it also has common dominant artistic and ontological features, which are most pronounced in literary and musical works. These forms and their dominant features should be understood as a system of functioning of iconic complexes and the principle of organizing individual parts as part of a whole composition, including a comparison of plot episodes, and the order of reporting the course of events, and the distribution of these events in time.

Being a necessary component of the musical and historical process as a whole, and the most important part of composer's creativity and musicological research thought, today the world musical gogoliana has more than 50 opera compositions, including almost all varieties of this genre, more than 10 ballets, numerous musicals and operettas. From the point of view of handling the primary sources - the compositions of N. Gogol, these musical and theatrical compositions can be divided into heroic and romantic, grotesque and satirical, lyrical, epic, fantastic and spiritual and philosophical.

A review of the genre-stylistic panorama of the musical gogoliana testifies to the fact that N. Gogol's work is the basis and a powerful impetus for the formation and development of almost all genre and style trends. It is able to inspire artists of different scales of talent, psychological makeup, different figurative and thematic priorities. Each historical epoch, each national culture discovers its own themes in the composition of the writer, takes creative impulses from him.

The exceptional demand for the writer's works in musical art is due, on the one hand, to the rich inclusion in their plot and figurative structure of music-making scenes, characteristics of musical art and its individual expressive elements, on the other hand, to the specificity of the literary language, which evokes rich musical associations. But the main thing is that Gogol's compositions are an anthology of penetration into the spiritual world of man.

Moreover, the psychological analysis is combined in their chronotope with a variety of characterological characters, written out realistically and uniquely.

Practically all artistic and subject areas of Gogol's work have been reflected in contemporary composer's work. These spheres transcend cultural, linguistic, national boundaries, affirming the immortal significance and universal artistic meaning of the heritage of the great writer.

\section{BIBLIOGRAPHY}

1. Веселовский А. Историческая поэтика. Москва : Высшая школа, 1989. 405 с.

2. Ганзбург Г. О перспективах либреттологии. Музыкальный театр ХХ века : События, проблемы, итоги, перспективы. Москва, 2004. С. 244-249.

3. Нилова Т. Оперная ситуация как основа морфологического метода анализа оперной драматургии. Теоретические проблемы советской музыки : сборник научных трудов. Москва, 1988. C. $49-62$. 
4. Нилова Т. Типология сценических ситуаций в русской классической опере. Методика морфологического анализа : автореф. дис. ... канд. искусствоведения. Москва, 1993. 24 с.

5. Томашевский Б. Теория литературы. Поэтика. Москва : Аспект-Пресс, 1999. 334 с.

6. Ярустовский Б. Драматургия русской оперной классики. Москва, 1953. 376 с.

\section{REFERENCES}

1. Veselovsky, A.N. (1989) Historical poetics. M.: Higher school. [in Russian].

2. Ganzburg, G. (2004) On the prospects of librettology. Musical theater of the XX century: Events, problems, results, prospects. M. [in Russian].

3. Nilova, T. (1988) Opera situation as the basis of the morphological method of analysis of opera drama. Theoretical problems of Soviet music: Complex of scientific works. M. [in Russian].

4. Nilova, T. (1993) Typology of stage situations in Russian classical opera. Morphological analysis technique. Author's abstract. dis. of Cand. of Art History. M. [in Russian].

5. Tomashevsky, B. (1999) Theory of literature. Poetics. Moscow: Aspect-Press. [in Russian].

6. Yarustovsky, B. (1953) Dramaturgy of Russian opera classics. M. [in Russian]. 